\title{
Ethics of Officials in the Context of (Slovene) Good Administration
}

Polonca Kovač ${ }^{1}$

\begin{abstract}
The author discusses various aspects of ethical conduct, referring to both individual officials and the public administration as a whole, in the sense of good governance. She underlines that the main ethical challenge for officials (seen as executors of public tasks) is to be responsive to the needs of the society in any type of activity falling within the competence of administrative bodies, such as designing new regulations and deciding on specific administrative matters. Considering the significance of public administration for the development of the society, the foundations of ethical conduct of officials are largely defined already in administrative law. The work of the officials is not mechanistic but rather involves the creation of law - although at a purely instrumental level - and is therefore responsible and ethically determined. Officials fulfil their mission as long as they act lawfully within the scope of their powers and comprehend the purpose of law, which is to protect general social benefit and public interest, together with human or legally protected rights and individual interests. Within the limits of their powers and regulations, they are called to solve life issues. Thus, they contribute to democratic and effective administration. The paper provides an analysis of selected aspects, dilemmas and practices arising at the level of individuals and the Slovene administrative system as a whole, at the intersection between work ethics, administrative law and good public administration. In terms of legal principles and ethical codes, Slovenia is considered a rather successful European country; nevertheless, in order to raise general awareness and put the officials' ethics in practice, a more proactive approach to governance and management is needed.
\end{abstract}

Key words: ethics, officials, good public administration, administrative law, principles, code of conduct.

1 Assistant Professor at the Faculty of Administration, University of Ljubljana, Slovenia, and President of the Officials' Council 2008-2011. 


\section{Public administration and officials}

\subsection{Definition of concepts}

Being determined by the individual's intellectual and emotional ability to distinguish between right and wrong, ethics is a concept that concerns both individuals and groups of people. Likewise, ethics in public administration can be considered from the viewpoint of individual officials. However, the ethics of individuals determines societal, community and individual values, as well as values and standards and the administrative culture pursued by the contemporary public administration as a whole. The social relevance or multidimensional character of the concept is particularly evident in the case of work ethics as it relates to viewpoints and beliefs concerning work and work-related activities which - being all elements of motivation - affect the employees' behaviour (Meriac et al. 2010, 315). Therefore, (work) ethics should be discussed at the level of officials as individuals and at the level of public administration as the organisation and further at the level of the social subsystem. The paper presents selected aspects of ethical guidelines and rules applying to officials that arise from the intersection of ethics, (good) public administration and administrative law, which also plays a key role given the legal determination and the nature of administrative relations in public administration (Figure 1).

\section{Figure 1}

Officials' ethics as the intersection of (work) ethics, (administrative) law and (good) public administration

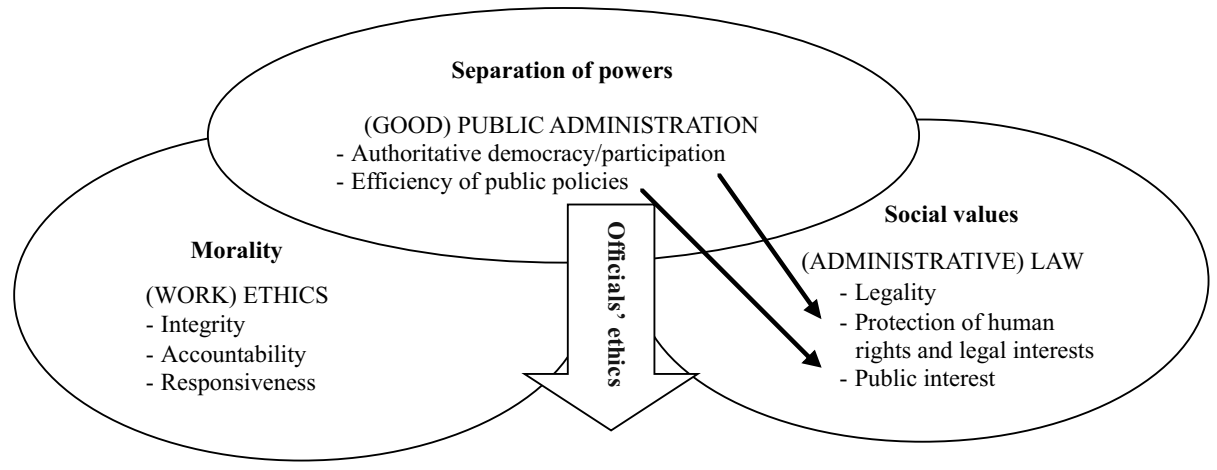

Public administration is a comprehensive phenomenon that individual authors define on the basis of several criteria, such as function (execution of - at least partly authoritative - public tasks), structure (state-administration bodies, municipal authorities, bearers of public authority, i.e. providers of public services), labour law and public finance (e.g. the system governing civil servants and wages in the public sector - which includes public administration - or general government fi- 
nancing from public funds), etc. (Godec 1993, Virant 2009, 18). In this paper, the term public administration is used in a rather broad sense, comprising entities or bodies with different statuses but all performing public tasks of authoritative (in particular, participating in the preparation and adoption of regulations and deciding in administrative procedures) and service nature with at least partial authoritative connotation (e.g. provision of public services at the level of the state and local government). Further on, they are broken down by activities, namely regulation or implementation (of regulations and other acts regulating the execution of public tasks). Generally speaking, public administration is a system encompassing all entities that decide on public matters and provide public services and thus contribute to the satisfaction of public interests ${ }^{2}$ and any legal interests of natural and legal persons toward authorities or public-service providers in accordance with the regulations in force. Nevertheless, public administration is a much narrower term than public sector (e.g. public administration employs about a third of a total of 160,000 civil servants of the Slovene public sector). At this point, it also needs to be underlined that in understanding the concepts of public administration and officials, a key role is played by the principle of separation of powers placing the officials under the Executive. This means that occasionally, different rules and criteria apply than, for example, for the Judiciary. Therefore, in their work, officials encounter similar and different ethical dilemmas than e.g. judges. ${ }^{3}$

Likewise, the concept of officials is dealt with herein in its broadest sense and not merely following the definition provided by the Civil Servants Act (Official Gazette of the Republic of Slovenia No. 56/02 and amendments), which means that the expression "officials" includes all persons who in their professional activity perform (also) public (authoritative) tasks although employed in state-administration bodies as administrative staff or even employed by private persons in the function of officials. The term "officials", however, does not include functionaries in public

2 There are several types of public interest (Kaye in Huberts et al. 2008, 197), particularly in relation to public tasks, yet the author will hereinafter use the singular form for public interest and plural for private interests, thus stressing that public administration is called to solve the collision between the prevailing public interest and several partial (group or individual) private interests.

3 It needs to be underlined from the very beginning that in this context, it is (at least) incorrect and professionally inaccurate (although acceptable in, e.g., textbooks) to use the term "official" with a negative connotation of bureaucratic and non-value-based work of a judge or even with a derogatory connotation. Officials are not machines whose only task it is to apply law in specific states of affairs. Quite often, in pursuing both public interest and the rights of the parties in e.g. administrative proceedings, officials are more ethically burdened and divided since - contrary to judges in law suits - their duty is not only to provide efficient legal protection to the parties; in fact, they "schizophrenically" and inevitably act as protectors of parties' rights, advocates of public interest, and at the same time also decision-makers (Jerovšek and Kovač 2010, 4). In doing so - given the principle of separation of powers and the administration's boundness to the law or acts of "higher" regulators - they must acknowledge public interest exclusively based on the regulations in force (even if such are inconsistent with the law) while judges are empowered by the Constitution to decide directly on the basis of the law (exceptio illegalis). 
administration (e.g. ministers, mayors) since officials and functionaries distinguish themselves quite strongly in terms of ethics; officials (even at the highest posts) are in fact supposed to be apolitical and professional. ${ }^{4}$ For the purposes of this paper, officials are thus persons employed in various organisations authorised to perform public tasks (e.g. also teachers deciding on educational measures, private doctors working on concession in case of decisions regarding compulsory health insurance, employees of chambers with mandatory membership or public agencies, and civil servants in state administration (approx. 35,000) and 211 municipal administrations (approx. 4,000)). In terms of generations - an important aspect of work ethics (Bluhm and Heineman 2007, 18) - public administration currently employs mostly the Baby Boomers (born between 1946 and 1964) and the Generation X (born between 1965 and 1980) as well as a small number of Generation Y (born between 1981 and 1999). Generations have a strong impact on ethics, and experts (e.g. Meriac et al. 2010, 321) note that Baby Boomers have an explicitly higher work ethic than the two younger generations. Thus, a general decrease of work values can be observed over time at the level of the community.

\subsection{Good governance and good administration}

Ideally, contemporary (Western) public administration reflects the changed role of the state and authorities in terms of good governance. Bearers of authority collaborate with other social subsystems, such as the economy or the civil society, through

4 In this paper, the terms "politics" or "(a)political" are understood as mechanisms of (democratic) supremacy in the struggle for power, while the term "policy" refers to political engagement of authorities to protect public interest or achieve common good (Kustec Lipicer 2009, 43, also on politics as "polity", i.e. institutional structure of authority). More on civil servants and their relation toward political functionaries in Korade-Purg in Kovač and Virant 2011, 119-147, and Virant 2009, 195. Cf. also the thesis (Brezovšek and Haček 2004, 147) whereby the relation between civil servants and political functionaries in contemporary administrative science is a specific problem of modern society as it reflects the contradiction between technical efficiency and democratic accountability and is therefore an important aspect of reflective behaviour in public organisations. However, it is crucial to understand the importance and irreplaceability of both actors in the process of governance: politics/functionaries at the institutional level and public administration/officials at the instrumental level of public administration (Žagar 2011,2 ). In modern society and science, the idea of fully apolitical public administration and officials is obsolete (Brezovšek and Haček 2004, 28). Despite the specific character of political functionaries - a law in Slovenia e.g. explicitly restricts their work in terms of incompatibility of functions and conflict of interests - it needs to be mentioned that in the 2004-2008 term, the Slovene Government applied a special code of ethics for ministers and state secretaries, which was consistent with the universal principles of democratic state and good administration set out below. This code had a final provision stating that a functionary acting contrary to the code should resign from office, which however never occurred in practice. 
participative strategic partnerships. ${ }^{5}$ The authorities primarily strive for the welfare of the individual and of the society as a whole, while ethical management is needed for public interest to prevail over private interests (Bluhm and Heineman 2007, 6). In a system of good governance, the state exercises authority with the aim of protecting general social benefit, but it is not the exclusive bearer thereof.

Within good governance, a set of principles and rules known as good administration has developed and recorded its greatest success with the inclusion of the right to good governance in EU law (Articles 41 and 47 of the EU Charter of Fundamental Rights, OJ C 83/337). Since the mid-1990s, this right has been taken into thorough consideration by individual EU Member States (Statskontoret 2005) as well as by the Council of Europe (Recommendation CM/Rec (2007)7), the OECD and the EU, particularly the European Ombudsman with the Code of Good Administrative Behaviour adopted by the European Parliament in 2001 and amended in 2005. ${ }^{6}$ The European Ombudsman and its national counterparts all strive for good or proper administration as opposed to maladministration, highlighting the principles of lawfulness, legitimate expectations, due conduct or fair procedure ${ }^{7}$,

5 About the many aspects of governance see Bevir et al. (2011); about ethics in governance see Huberts et al. (2008). For example, two systems of authority can nowadays be identified: on one side, there is the government with hard public law, exclusively public regulators, a state-centred system of democracy, and hierarchically conducted reforms, while on the other side, science (and practice, to a lesser extent) suggests a system of governance based on soft law, equal to private law, adopted together by public and private entities while democratic reforms are deemed socially grounded and are conducted through networking and open structures (Schuppert in Bevir et al. 2011, 289). The subject matter of and the relation between good governance and good administration are specified by the Venice Commission (2011, 14-19), focusing e.g. on predictability and proportionality, individuals' rights of defence in their relations with the administration, action taken within a reasonable time limit, etc. Despite the globalisation of trends and EU law, there are significant differences in interpretation among individual countries as regards regulation and implementation of principles, including e.g. the specifics of transition countries (Boštic et al. 1997, 17, Statskontoret 2005, 73).

6 The first attempts of global codification include the OECD analysis defining the key values of public administration in individual states and the Sigma code of ethics in the public service (1998). The EU Ombudsman Code of 2005 was partly replaced by the new Code of Good Administrative Behaviour adopted by the European Centre for the Development of Vocational Training and scheduled to enter into force on 1 July 2011 (OJ C 285/03). This Code highlights the principles of lawfulness, absence of discrimination, proportionality, absence of abuse of power, impartiality and independence, legitimate expectations, consistency, fairness, courtesy, reply, right to be heard, duty to state the grounds of decisions, the possibility of appeal and data protection.

7 Ethical standards are both procedural and substantial (Dorbeck-Jung in Hondenghem 1998, 51). Such a correlation is indicated also by the increasing importance of codes in the countries where procedural safeguards are not prescribed by law (e.g. France, USA; Suwaj and Rieger 2009,149 ). The entire infrastructure of integrity should, according to the OECD, combine: legal framework, i.e. control; ethical codes, i.e. guidelines; and coordination, i.e. system management. 
absence of abuse of power, proportionality, reasonability, etc. ${ }^{8}$ Good administration ensures that constitutional safeguards based on human respect or dignity are put into operation: the separation of powers, equality, proportionality, lawfulness. The real value of the right to good administration (and good governance) is that it ensures every individual or legal entity an impartial and just consideration of their case within a reasonable time, whereby they must have the possibility to be heard and make statements in any EU official language and have access to all information in their case; the administrative decison must be grounded, and the plaintiff must be given the possibility of compensation (an analysis of the situation in Slovenia in terms of regulation and practice is provided by Kovač and Virant 2011, 208). Good administration is administration that allows the addressee of the authoritative norm or holder of the right the fulfilment of their interests unless they are contrary to public interest. This is also provided by the General Administrative Procedure Act (Official Gazette of the Republic of Slovenia No. 80/99 and amendments, GAPA), namely Article 7 - primarily, the duty of the official is to enable the party to exercise their right, and only secondarily, although cumulatively, the possible collision with public interest and the rights of third parties are examined since the rights involved are generally positive rights, the recognition of which the state examines through individual fact-finding procedures and guarantees them only upon the fulfilment of pre-set conditions.

Good administration is to be provided by individual officials, yet at the level of the system as a whole, it falls under the responsibility of the legal regulation of authority and public administration and of flexible management, particularly the principal of the individual administrative body. Law is in fact static and universal and cannot define all possible life situations (only normative idealism and the consequent casuistry of creation of regulations show otherwise; critics thereof are available in Boštic et al. 1997, 13, Vlaj 2006, 16, Igličar 2011, 22). Even more, officials (on positions) must make sure that in the event of detected deviations between the goals of public-task regulation and its implementation, they - through the regulatory loopback - pass information about the need for amending regulations and thus allow the authorities to act lawfully (according to regulations in force) and legitimately (so that the regulations in force comply with the main values of the community and social reality). This applies to both regulatory and implementation functions of public administration (Barnes in Rose-Ackerman and Lindseth 2011, 349).

8 In certain cases, good administration is established even in situations that are contrary to lawfulness, if and when - upon discretion - proportional action would require a milder or different measure than the selected and otherwise lawful measure (see models and examples from the British and Dutch Ombudsmen in Remac and Langbroek 2011, 5-16). Thus, a lawful yet proper and non-bureaucratic conduct is expected. Tools against misgovernment therefore combine control, solidarity and self-regulation, competition and randomness (Hood in Hondenghem 1998, 10-14). 


\section{Administrative law as reflection and source of ethical guidelines}

When, particularly in relations with private operators, officials act as authority or public service, their work - given the public nature of their tasks and the importance of public management in the society - is guided by public law, above all constitutional and administrative law. A violation of the ethical principles and standards in the relations between the representatives of public administration and the users of public service or addressees of the authoritative norm is therefore considered unlawful conduct rather than just bad practice. For example, pursuant to GAPA, an official who is not impartial may not participate in administrative proceedings since this conduct - i.e. either refusing to recognise rights to a party whom the official is unfavourable to although the party meets the necessary conditions, or by recognising excessive benefits contrary to regulations and public interest - is unethical as well as unlawful (Androjna and Kerševan 2006, 152, Jerovšek and Kovač 2010, 7, 81). ${ }^{9}$ The purpose of this exclusion is not only to guarantee the objectivity of proceedings but also to protect the integrity of an official or body (Rakar in Vlaj 2006, 42).

(Administrative) law is therefore (also) a tool of ethical public management or governance. And vice versa - legal principles, i.e. principles defined by law, are ethically binding as they represent value-based criteria governing the definition and implementation of specific legal rules (Androjna and Kerševan 2006, 74). For this reason, officials must take account of the intersection of moral and legal norms (Figure 1, Igličar in Vlaj 2006, 10). It is no surprise that, particularly in times of social crises, law is applied to examine what are/were the basic social values. Only moral and legal norms together make up the integrity of the official. ${ }^{10}$ Integrity (the internal moral norm) and accountability (the external norm) together stimulate the

9 GAPA regulates the exclusion of officials from the proceedings in Articles 35-39 and sanctions violations as fundamental procedural errors in appeal or fact-finding proceedings (Article 237(2) (6) and Article 260(6)). A distinction is made between absolute partiality as undisputable fiction (iudex inhabilis), when for example the official is a close relative of the party, and relative partiality (iudex suspectus) which is assessed on a case-to-case basis. Another difference is that in a situation where there are absolute reasons for exclusion, the official must immediately cease to conduct the procedure, which is not the case in the event of relative reasons. It needs to be mentioned that Article 37 of GAPA - defining any circumstances which cast doubt on the independence of the official to be reasons for exclusion - is intentionally left indefinite, in order to encompass all possible situations of collision of interests. However, the official, his/her superior and the party must make up for the indefinite nature of the legal concept with specific subject matter and personal integrity.

10 Cf. various authors, e.g. Six and Huberts in Huberts et al. 2008, 66, 252. Ethics and integrity are topics dealt with in philosophy (mother of all sciences), law and criminology, sociology, history, psychology, economy, political sciences (public-policy analysis; Bluhm and Heineman 2007, 22-69), business administration, administrative science. Ethics studies moral values at the level of the individual and professional or otherwise related groups. Hence, the distinction between meta-ethics, normative ethics and applied ethics (Suwaj and Rieger 2009, 20). 
reflection of the official as well as the necessary autonomy and responsiveness of public administration. Three types of integrity are therefore distinguished, namely personal, political and financial integrity, together forming what is known as Beamtenethos (Dorbeck-Jung in Hondeghem 1998, 49, 155).

\subsection{Values as source of administrative law, public administration and public interest}

Law is composed of norms, relations and values, whereby values (as ideas pursued in the conduct of people) and interests are a prerequisite for regulating social relations and simultaneously the subject matter of regulation through legal norms (Igličar 2011, 15, 26, Pavčnik 2007, 599). Law is therefore more than a purely abstract regulation of relations between individuals and communities as it strives for justice within the society. If public administration designs and implements law otherwise, it acts as a mere bureaucratic administrative apparatus. Yet public administration and its officials must always act in accordance with the law; if they bypassed the law and individually assessed whether or not a certain regulation is lawful, they would embark on a path of self-will and certainly exceed the constitutional principle of separation of powers. Given the basic value and principle of public law, which is to protect public interest in accordance with the law, lawfulness may well be considered a minimal prerequisite for the ethical conduct of officials. Yet being bound by the law does not mean that an individual norm is to be observed to the letter - quite the opposite, laws must be designed, interpreted and applied within the context of the entire constitutional order. Given the general nature of legal acts, it is necessary to interpret undefined notions in accordance with the basic principles of public law and recreate regulations that are not (or no longer) consistent with the needs of individuals and the community as a whole.

Both legal rules and ethical standards must derive from individual, group or community values. In methodological terms, the following sequence can be recorded in both law and ethics: (a) values, (b) principles, and (c) rules or standards (Vermeulen in Hondeghem 1998, 523, e.g. the principle of separation of powers is put into operation by means of the standards of transparency and reporting and by means of legal protection against administration before the court). The hierarchy of such concepts should lead us to respect what is (more) important. Yet theory and regulations do not provide a uniform indication as to when a certain notion is to be defined as value, principle, or (merely) standard. Equality, for example, is considered a value (EU Treaty), a principle (Article 14 of the Slovene Constitution), as well as a common rule (individual lower acts). Despite a certain degree of confusion as regards the distinction and understanding of the above notions (cf. the formally separated yet substantively overlapping articles of the Decision on Code of Good Administrative Behaviour relating to lawfulness, impartiality and objectivity), their overlapping demonstrates that human rights and freedoms - either systemic (e.g. protection of human dignity), substantive (e.g. prohibition of torture) or procedural 
(e.g. right to efficient legal remedies) - are the core value and simultaneously a legal and ethical principle or guideline and rule, i.e. standard. The legislature (parliament) is thus called to transform largely accepted values into legal norms (Igličar 2011, 19), yet in designing public policies (e.g. analysing the state of affairs and preparing the relevant materials or legislative drafts) and in the implementation thereof, the Executive and its public administration - together with the Judiciary - inevitably play an important role and, as a consequence, also bear responsibility. The same applies to the process of modernising public administration and New Public Management, although adding certain new values and principles - such as efficiency and effectiveness or entrepreneurship - to the classic values might pose an obstacle to ethical judgement (e.g. delegation of public tasks outside the administration might jeopardise the democratic accountability of authorities; Hondeghem 1998, 3, Kovač and Virant 2011, 30). Some authors (Brezovšek and Haček 2004, 29, 31, cf. Table 1) distinguish between:

1. Market, political (accountability, responsiveness, legitimacy, fairness, openness, etc.) and legal (lawfulness, protection of rights, fair procedures, accountability, etc.) values, and

2. Democratic and professional (efficiency, competence, reliability, etc.) values (OECD 1996).

Considering that public administration is part of the Executive and has an explicit political connotation (seen e.g. in the dual role of ministers as members of the political government and simultaneously heads of basic administrative bodies i.e. the ministries), officials and parties in administration inevitably present elements of legal, political, administrative and managerial culture. ${ }^{11}$

Table 1

Types of organisational culture in public administration (Koprić 1999, 281)

\begin{tabular}{|l|c|c|c|}
\hline \multicolumn{1}{|c|}{ TYPE OF CULTURE } & \multicolumn{3}{|c|}{ Values } \\
\hline Officials' orientation & Legal & Political & Economic (market) \\
\hline Professional-proactive & Legalistic & participative & Entrepreneurial \\
\hline Official-reactive & bureaucratic & authoritative & Managerial \\
\hline
\end{tabular}

Given the complexity of public administration, the existence of different cultures and practices in different environments (legal systems) and, by analogy,

11 The professional-proactive orientation from Table 1 could be described as value-based or resultsfocused, while the official-reactive orientation can be said to be compliance-based or focused on procedural rules (cf. Hoextra in Huberts et al. 2008, 149). 
in various segments of public administration of individual countries ${ }^{12}$ is ethically significant. Considering the trends of globalisation and convergence, modern administration is characterised by a combination of different approaches: thus, for example, developed democracies from North to South and from West to East present - although fully respecting legality and accountability - an increasing degree of pro-activity, responsiveness and participation. In the adoption of general acts and in administrative proceedings, the Slovene system and practice strive toward an excessively detailed regulation and bureaucratic understanding of merely a fragment of the party's life situation, without any responsibility for the accountability of the system as such (Kovač and Virant 2011, 198). For this reason, it would be wise for the future to follow the example of the countries that have a more abstract legal system, with emphasis on the basic principles as fundamental value criteria. ${ }^{13}$ Good administration is administration that creates and implements regulation not strictly to the letter of the law but rather for the purpose for which it has been adopted as general good. Yet since culture reflects the values, expectations and behaviours of the people within and toward administration, it is necessary and ethical to examine both aspects, i.e. the conduct of officials toward the parties and vice versa (Maes in Hondeghem 1998, 119, Six and Huberts in Huberts et al. 2008, 69). In other words - the ethical conduct of officials and public administration is directly related with the ethics of the persons and organisations entering the relations with public administration. Only together can a higher degree of (legal) culture and democracy be achieved. Thus, as recommended by the EU, "education for democratic citizenship" should also be encouraged (Žagar 2011, 10). Parties in administration should not be seen merely as users seeking benefits even by means of an excessive assertion of (procedural) rights, but should also recognise and accept their share of responsibility for a system of good governance. The law is in fact based only on the presumptions of free will and rational conduct of the people, and education should necessarily include the ethical conduct of the parties. Everyone, from politicians on one side to entities subject to public obligations on the other, should at their own personal level exercise rights not only for the sake of formality or random advantages that law offers to individuals, but when a right is legally and ethically just(ified). In particular, it is unethical to $(\mathrm{ab})$ use procedural law for purposes contrary to those arising from the definition of a certain legal entitlement. Such practices do not promote a

12 Koprić $(1999,275)$ refers to legal-political values as being more a characteristic of the continent, while political-economic values derive from a pragmatic environment, such as the USA. Within individual countries: given the stronger ties with the local environment, there are evident differences in the work of municipal administrations and officials compared to those at the state level (more in Vlaj 2006).

13 This also applies to codes of ethics. Cf. the concept of the Code adopted by the Slovene Officials' Council (2011), which is based on only ten briefly defined, value-based guidelines of ethical conduct of civil servants. This value-based Code analyses - in a general and universally applicable manner - the ethical dilemmas and can be practically applied in any situation and time (Stare 2011, 3). 
positive and proactive entrepreneurial culture but rather aim at commercialisation and sale of public interest.

In public matters, law, public administration and officials must - in order to act legitimately and fairly - act in accordance with general social interests. ${ }^{14}$ Yet not every interest for the society or the majority can be considered a "public interest". In terms of subject matter, public interest can indeed be defined as interest of the social majority that is in accordance with fundamental human rights or minority rights, while formally an interest is considered public when and in how far specific values as such are included in the existing law by the competent regulator. In implementing the regulations, public administration is - owing to the principle of separation of powers - strictly bound by the legally defined public interest, although in specific cases officials still need to establish public interest upon consideration of the actual state of affairs. Which and to what extent the majority and democratic values and practical needs will be included in a specific regulation is co-defined by public administration through its participation in policy-making as a substantive legislator. The public (political) conduct of functionaries as (programme) officials should reflect basic values, such as democracy, the respect of human rights and human dignity, and social welfare. ${ }^{15}$ The conduct of officials is therefore highly important; in addition, it is ideology-based and ethically more sensitive than e.g. conduct in the private sector. Particularly if one considers the complexity of contemporary life and, as a consequence, the increasing power and volume of public administration. Therefore, the actions of public administration are directly related to trust (or more correctly: trustworthiness) in the democratic nature of authorities and the state (Brezovšek and Haček 2004, 19, 44, 255), which also distinguishes the values and ethics of public managers from private managers (Fawcett and Wardman in Huberts et al. 2008, 123). Officials are the bearers of trust and authority and are therefore obliged to justify trust and refrain from abusing power. Ethics in the public sphere is important to provide democracy, lawfulness, and security (Maquire and Vermeulen in Hondeghem 1998, 24, 173, Boštic et al. 1997, 14).

14 Cf. interests and collisions of interests in legislative policy and at specific levels (Godec et al. 1993, Considine and Afzal in Bevir 2011, 374 ff., Igličar 2011, 25-31). State bodies are by their nature bound by and subordinated to certain public interests - for various "entitlements", for apparent "dispositive" dispositions and even for "the right to free judgement" (Pavčnik 2007, 128). The task of the law and of the users thereof is to solve conflicts of interests in mutual relations, and in administrative relations with proportional and a priori supremacy of public interest (Androjna and Kerševan 2006, 93 ff.). Personal - although legal - interests can be asserted only within the scope of public interest. Public interest is the "cardinal" value of the public sector, providing for the legitimacy of its outcomes (i.e. output legitimacy - as opposed to respect for procedural rules among the participants, i.e. input legitimacy; Considine and Afzal in Bevir 2011, 371).

15 Kustec Lipicer 2009, 59. Cf. the same for private managers (Primožič and Mesner Andolšek 2011, 264), which reflects the interrelatedness of social subsystems or the existence of social accountability also in the profit sphere. 


\subsection{Administration between democratic restriction of authoritative self-will and public-policy effectiveness}

In a democratic society, the public sector acts legitimately when its power derives from the will of the people and accountability mechanisms are established; moreover, authorities need to be collaborative (i.e. collaborative governance) and act in accordance with the principles of participation and dialogue when general policies are being adopted and implemented. Legitimacy is based on the specific objectives of public policies, on the transparency of results, on the accountability for errors and on the revision of programmes. In implementing public tasks, the administration and officials must therefore take into consideration as follows (Bevir 2011, 12):

a) Legal rules (of administrative law);

b) Professional standards (by areas of work, e.g. social work, environment, biotechnology, defence, cf. the analysis of (un)ethical practices in Bluhm and Heineman 2007, 130-194);

c) Personal ethics.

Administrative law and professional administrative standards require the authorities to be both democratic by protecting fundamental human rights and effective in the implementation of public interest (Kovač and Virant 2011, 206). Particularly in an authoritative system, administration is deemed effective if it provides power to the governing option whereas the modern state, based on international standards, also measures the effectiveness of its administration in terms of effective protection of the rights of individuals, i.e. in terms of accessibility of administration, speedy recognition of rights and legal interests, equality of the parties before the law, etc. ${ }^{16}$ In order for public interest to prevail, the administrative body regulates and decides in the relations with the addressees of legal norms with a pre-defined supremacy over individuals. Nevertheless, the administration allows the users to participate in the procedures, either by public participation in the adoption of laws or by means of procedural entitlements in administrative proceedings. A proper and timely confrontation of various interests maximises the consensuality of relations and decisions, which contributes to the rule of law since also authoritative decisions that are less convenient for the parties are more strictly observed and ethical issues eventually resolved. Effectiveness is thus understood as correctness of action, i.e. full implementation of applicable law. Theoretically speaking, this implies rationality in the sense of consistence of the legal system with the facts of life - if deviations arise, the loopback can be used to amend the law. Particularly important for

16 Weber speaks of "technical rationality" (in the sense of fulfilling the objectives - Zweckrationalität) where the administration or its actions are rational and the expected results exceed the burdens, and of "value-based rationality" (Wertrationalität), which is also very important (Kovač and Virant 2011, 211). The responsibility for such conduct lies primarily on the legislature as well as on the executor of regulations, i.e. public administration that participates in drafting and implementing regulations. 
effective implementation is, above all, a uniform and unambiguous understanding of the purpose of the regulation.

Even as regards specific and individual administrative relations where the degree of preciseness of rules (lex certa) and the a-priori protection of public interest - compared to the legal interests of individuals - as well as the determination of (uniform) actions, the exceptionalness and the low level of discretion of officials are - by the nature of activity - the highest, the basic GAPA provides partner principles or rules. This is becoming more and more obvious with the amendments of GAPA toward good administration, the reduction of administrative burdens, the introduction of alternative dispute resolution, etc. in administrative matters (Jerovšek and Kovač 2010, 9). The administrative body should act as a partner of the party and collaborate with them as long as their interests do not infringe upon the rights of third parties and public interest, following a principle of user-friendly public services as provided by the Public Administration Act (Official Gazette of the Republic of Slovenia No. 52/02 and amendments, ZDU-1). The modernisation of the Slovene general administrative procedure follows the development of administrative procedure that derives from the restriction of absolutistic authority; in case of doubts concerning an individual provision, the interpretation that favours the individual should be chosen (in dubio pro reo), which is a classic legal as well as ethical principle (of power). This idea is pursued by the legislature when, for example, transferring the burden of data gathering from the parties to administrative bodies, abolishing limited local jurisdiction, introducing e-commerce, allowing the waiver of appeal, and even in the field of inspection when turning from exclusively arbitrary decisions to service and counselling. On the other hand, administrative law and the actions of public administration increasingly lean toward greater (technical) efficiency since an advance provision of procedural safeguards in the absence of a dispute or in a case with no significant weight can lead to an (unnecessary) waste of time and (limited) resources, as well as to restricted adaptability to attain the objectives of the administrative body. The need for regulating the relations between the parties in the procedure should be proportional to the rate of conflictuality of relations and to the weight of the action since a stronger action also requires a higher degree of protection of the parties (Harlow and Rawlings 1997, 504-523). Therefore, in administrative relations, it is necessary for the administration to trade off between effectiveness and fair result. The main message of modern public administration is to pursue a balance between or a simultaneous duality of guarantees of both public interest and the rights and legal interests of the parties and other stakeholders (Statskontoret 2005, 78).

Since it is impossible to legally define all life situations, a greater indefiniteness and, consequently, the assumption of responsibility for value-based and legally correct decisions made by officials are necessary. In striving for an effective public administration, greater abstractness of regulations and public interest could - despite the respect for (minimum or partial) lawfulness - lead to a misunderstanding 
of the relations between politics on one side and the administration, i.e. regulations and professional standards of administrative work, on the other. The work of the official is not only to provide service to political structures (Boštic et al. 1997, 20). According to Igličar $(2011,46)$, the function of politics is to prioritise the values from the political party's programme into social rules by means of power or authority, even by outvoting, while the function of law and the public administration bound thereby is to stabilise the relations by regulating conflicts on the basis of legal norms adopted in advance that are the same for all. This is the rule of law or Rechtsstaat that binds together lawful and legitimate.

\subsection{The definiteness of (administrative) law and accountability in administration in proportion to ethics}

The precondition for lawful and legitimate conduct (within and in relation to public administration) in accordance with public interest is the exactness and definiteness of (administrative) law. The exactness of regulations contributes to legal certainty, and it is legally and ethically inadmissible to expand the legal rule to cases that are not unambiguously covered thereby (Igličar 2011, 174). The inexactness of regulations, an excessive number of laws and the unworkable nature thereof, an inadequate control by control institutions and excessive discretion rights are all direct reasons for corruption (Dobovšek in Brezovšek and Haček 2004, 221). This can also be explained by the formula (Suwaj and Rieger 2009, 356): Monopoly + Discretion - Accountability $=$ Corruption in administration.

On the other hand, despite the efforts for quality and definiteness, the rather general nature of regulations always allows a certain degree of creativity or (in nonlegal words) "discretion" for developing hierarchically lower general legal acts and applying general rules to specific cases. Given the explicit dynamics of the social environment, the administration must include new value- and ethically based premises even in specific decisions. ${ }^{17}$ In fact, officials, i.e. public administration - although at a lower or instrumental level of public management -, also define public policies when implementing regulations and other acts issued by institutional regulators

17 Adams and Balfour (in Huberts et al. 2008, 85) illustrate the "ethical paradox" - namely that the society judges the behaviour of individuals not so much based on the result of their (objective) behaviour as such but rather in a social and cultural context in which such behaviour is manifested - by drawing upon the examples of von Braun and Schindler in Nazi times. Long after the war, von Braun continued to be a distinguished scientist in the USA despite his evident contribution to the success of Nazi Germany while Schindler - although he had saved the lives of many Jews - remained an unsuccessful entrepreneur and his application to enter the USA was denied. 
(political bodies). ${ }^{18}$ Compared to the institutional management at the parliamentary or government levels, the administration is apolitical and professional. A sovereign state is based on democratic elections and legitimacy, while the administration has an instrumental character. Ideally speaking, the administration and the officials are politically neutral when implementing politically defined goals, thanks to the standard ministerial structure that is bound by the law and characterised by hierarchy, accountability, and judicial and parliamentary control. Nevertheless, officials have a "political role" since in developing and implementing public policies, they act within the scope of value-based and ethical dimensions (Koprić 1999, 276).

Despite being bound by regulations and the interpretation thereof by the legislature and the courts, public administration is still left a certain degree of creativity which, however, is only possible within the limits of legally provided discretion. This does not imply a lack of respect of public interest but rather enables this interest to be observed. Thus, administrative law and even administrative proceedings provide for both substantive and procedural discretion (Androjna and Kerševan 2006,85 ), which allow decisions that are as appropriate as possible. Yet acting at discretion is limited to positions explicitly provided by law and has to comply with the basic legal principles, particularly proportionality (GAPA, for example, provides that when forcing a party to act in the public interest, the executive body may considering the circumstances - provide for forcible execution either by fine or by other persons, whichever is milder for the party yet still consistent with the regulation). The application of law, although by means of an individual administrative act, is per se the act of its creation and a political process. This is particularly true since the scope of discretion (both substantive and procedural) in administrative law increases parallel with the diminishing degree of definiteness and hierarchy of the regulator as a result of the complexity of the subject matter of legal regulation. In this context, growing importance is assumed by procedural administrative law, which is directly proportional to a lower definiteness of substantive law (Barnes in Rose-Ackerman and Lindseth 2011,342). The necessary condition for a correct decision is the correct definition of both premises, i.e. the (uniform) understanding of the general norm (in terms of substantive and procedural law) or the abstractly legal actual state of affairs. The role of public administration in the interpretation of law

18 More on public management in Godec et al. 1993, Pavčnik 2007, 406, Virant 2009, 14 and the following. The administrative activity is not an end in itself (Pavčnik 2007, 577) since the administration is "a professional and indispensable yet auxiliary activity that provides grounds for the conduct of the basic activity." Such definitions are important as they show that the administration is related to and dependent on the entire administrative and political subsystem and that it plays an instrumental role in the development and work of the society as a whole. Such distinction gives grounds to dualistic theories (e.g. Kelsen) on the principle of separation of powers whereby the power of the state is distributed among decision-making (legislative bodies) and execution (executive and judicial bodies). The distinction between administrative and other issues is based on the degree of administrative work, legal judging and decision-making (Pavčnik $2007,287)$. Considering the role of public administration, this is a necessary and very important element of policy networks (Brezovšek and Haček 2004, 255). 
is - considering the principle of separation of powers - not uniquely determined but it is restricted although over time and considering globalisation, the distinction between the classic branches of power is no longer as strict as in the $19^{\text {th }}$ and $20^{\text {th }}$ centuries.

A distinctive feature of public administration and of the system of officials - mainly as opposed to judges who also apply regulations in specific cases - is hierarchy. The latter is no longer a mechanistic concept as in Max Weber's times but remains of key importance in terms of the definition of accountability of individuals (subjective and objective e.g. at the level of principals), of bodies, and of the state or authority as a whole (Article 26 of the Constitution). In theory, the following forms or aspects of accountability exist:

1. Institutional or administrative: in a relation beyond the administrative system or official (answerability), and legal in the event of mistakes (responsibility);

2. Professional: in the sense of affiliation with the system of values of civil servants (professional accountability), and personal including actions in line with personal ethics (personal accountability; Bevir 2011, 373-375, cf. Suwaj and Rieger 2009, 152).

An efficient accountability mechanism comprises functional and ethical aspects; the first should provide for consistency of public policies with public interest and the latter for their reliance on moral standards. Here, in order to establish accountability, it is necessary to develop at any level the respective system of accountability and powers and ensure that each is held accountable (only) for their own scope of influence. ${ }^{19}$

Accountability needs to be provided in particular when contracting out, i.e. delegating public powers outside the administration, where there is a less rigid relatedness with politically accountable line ministries, a culture different from administrative culture and a lower degree of sensitivity for and competence of the classic values of the administration, which increases the possibility of corruption. ${ }^{20}$

19 The apparently formalistic rules (e.g. Article 216 of GAPA, whereby a decision that is being issued is to be signed by the official who conducted the proceeding although they might not agree with the decision of their superior, since they - within the scope of their powers - are responsible for the lawful conduct of the proceeding) are thus not irrelevant.

20 In the private sector - even if the company holds the concession to provide a public service different values and personal motivation mechanisms apply (e.g. wage depending on company's profit), which could provide grounds for a conflict of interests. Therefore, the expansion of administrative activities and the transfer of public tasks to the private sector imply a higher risk of unethical behaviour (Cohen and Eimicke in Bevir 2011, 245-249). The decentralisation of decisions is accompanied by the decentralisation of ethical values since accountability is distributed (Žagar 2011, 6). For this reason, control mechanisms need to be developed, such as defining which public tasks cannot be delegated to private providers (e.g. tax collection, police and fire protection in the USA) and developing legal methods to implement public values (e.g. with procedural rights of the parties) also among private providers (Auby in Rose-Ackerman and Lindseth 2011, 515). 
In fact, the hierarchy of relations within the administration and between public administration and other institutions and the accountability of all for responsiveness and mistakes provide for the existence of representative democracy (Bevir 2011, 8). For example, despite the principle of independence of administrative bodies (Article 120 of the Constitution and Article 12 of GAPA), accountability in administrative matters is reflected in internal hierarchical relations, the application of legal remedies within the limits of the supervisory right or accountability of line ministries and the Government in relation to lower bodies, and in the fact that administrative bodies are bound by the decisions of the courts (cf. Articles 251 and 274 of GAPA and Article 64 of the Administrative Dispute Act, Official Gazette of the Republic of Slovenia No. 105/06 and amendments, ZUS-1). The accountability of individual parts of the administration and of the administration as a whole is provided (according to GAPA) by the rules concerning hierarchy and by constitutional principles such as separation of powers (Article 3 of the Constitution) in a horizontal (in relation to administrative acts seen as the implementation of decisions of the legislature and simultaneous subordination to judicial authority) and vertical sense (in relation between the state and local communities). Furthermore, accountability is also found at the level of individuals in the administration and is borne, in addition to the directly authorised official, in particular by their principal and body as a public manager of lawful, ethical, and efficient work. The indirect or objective accountability of the principal is evident at the outside ${ }^{21}$, while their direct accountability is seen in the manner in which they conduct and maintain dialogue with the people, with clients and officials. ${ }^{22}$

\section{Legal and ethical principles for officials and (Slovene) administration}

In order to determine whether and to what extent Slovene regulations comply with theory and international standards, an analysis was made of the most widely applicable regulations defining legal and ethical principles either in relation to officials or public administration as a whole (Table 2). Generally speaking, the Slovene regulation is consistent with global trends, which is a necessary yet not sufficient

21 Androjna and Kerševan 2006, 118. However, objective accountability (and minor offence accountability for the (non) functioning of a (public) legal entity) only arises if a principal's responsibility or duty to supervise e.g. the omission of a subordinate is exactly defined in the law, and the person responsible cannot be criticised for failing to exercise due control. Cf. the Supreme Court case No. Iv Ips 92/2008 on assessing the accountability of the mayor as principal of the municipal administration under which the water provision plant operates. Since in this case, the regulations and acts on the internal organisation of the administration provided for direct accountability of the official, i.e. the head of the relevant section, this official is held accountable rather than the direct legal representative of the municipality (i.e. the mayor).

22 Denhardt and Denhardt in Bevir 2011, 428-431. Or: forced ordinances are not effective in internalising ethical rules (Koprić 1999, 279). The principal should therefore serve as a model as well as a promoter of the development of competences of subordinate officials (Vlaj 2006, 103). 
component of good practice. International comparisons in fact show that Slovenia has a model regulation which, however, does not guarantee a high level of ethical standards of functionaries or officials in practice (Integriteta 2012).

Table 2

Overview of principles contained

in regulations governing public administration and/or officials

\begin{tabular}{|c|c|c|c|c|c|}
\hline & $\begin{array}{c}\text { Constitu- } \\
\text { tion }\end{array}$ & $\begin{array}{l}\text { Civil Serv- } \\
\text { ants } \text { Act }^{23}\end{array}$ & $\begin{array}{l}\text { Civil Serv- } \\
\text { ants Act - } \\
\text { officials }\end{array}$ & $\begin{array}{c}\text { Public Ad- } \\
\text { ministra- } \\
\text { tion Act }\end{array}$ & $\begin{array}{c}\text { General Ad- } \\
\text { ministrative } \\
\text { Procedure Act }\end{array}$ \\
\hline \multicolumn{6}{|c|}{ General legal principles (of democracy) of authorities (and public administration) } \\
\hline $\begin{array}{l}\text { Legal } \\
\text { protection and } \\
\text { predictability }\end{array}$ & $\mathrm{x}$ & & & $\mathrm{x}$ & \\
\hline Legality & $\mathrm{x}$ & $x$ & & $\mathrm{x}$ & $\mathrm{x}$ \\
\hline $\begin{array}{l}\text { Respect } \\
\text { of human } \\
\text { dignity } 24\end{array}$ & $\mathrm{x}$ & & & $\begin{array}{l}\text { Through } \\
\text { client- } \\
\text { orientation }\end{array}$ & $\begin{array}{c}\text { Part of } \\
\text { protection of } \\
\text { parties' rights }\end{array}$ \\
\hline $\begin{array}{l}\text { Protection of } \\
\text { human and } \\
\text { minority rights }\end{array}$ & $\mathrm{x}$ & & $\begin{array}{l}\text { Through } \\
\text { rules (e.g. } \\
\text { language) }\end{array}$ & $\begin{array}{l}\text { Through } \\
\text { rules (e.g. } \\
\text { language) }\end{array}$ & $\begin{array}{l}\text { Through rules } \\
\text { (e.g. language) }\end{array}$ \\
\hline Equality & $\mathrm{x}$ & & & $\begin{array}{l}\text { Through } \\
\text { legality }\end{array}$ & $\begin{array}{l}\text { Through } \\
\text { legality }\end{array}$ \\
\hline Responsibility & $\mathrm{x}$ & $\begin{array}{l}\mathrm{X} \text { - results } \\
\text { and good } \\
\text { manager }\end{array}$ & & $\begin{array}{l}\text { As part of } \\
\text { effective- } \\
\text { ness }\end{array}$ & \\
\hline $\begin{array}{l}\text { Effective legal } \\
\text { remedies and } \\
\text { judicial control }\end{array}$ & $\mathrm{X}$ & & & $\mathrm{x}$ & $\mathrm{x}$ \\
\hline
\end{tabular}

23 The Civil Servants Act provides ten principles common to all civil servants in the public sector (Articles 7-15a; the principle of prohibition of harassment was added with a subsequent amendment to the Act) and five principles applying to officials performing authoritative tasks in state and municipal bodies (Articles 27-32; the principle of protection of professional interests was deleted with a subsequent amendment to the Act). Hence, there are similarities between the principles applying to officials pursuant to the Civil Servants Act and the principles applying to administration pursuant to the Public Administration Act.

24 This "primal principle" is contained in Articles 21 and 34 of the Constitution. Article 21 provides for the protection of human personality and dignity in legal proceedings, while Article 34 guarantees the right to personal dignity and safety to every person (even outside legal proceedings). In the German Grundgesetz, for example, this basic value - on which (Western) democracy is founded - is mentioned already in Article 1, providing that human dignity is inviolable and the duty of all state authorities (Die Würde des Menschen ist unantastbar. Sie zu achten und zu schützen ist Verpflichtung aller staatlichen Gewalt ...). Likewise, (the right to) good administration is not specified by Slovene laws although it is to be directly applied pursuant to the EU Charter of Fundamental Rights. Good administration is otherwise a legal principle, defined at the level of the constitution e.g. in Finland (Article 21, cf. Statskontoret 2005, 15), while Romania intends to include such safeguard in its constitution following the 2012 revision. 
Table 2

(continuation)

\begin{tabular}{|c|c|c|c|c|c|}
\hline & $\begin{array}{c}\text { Constitu- } \\
\text { tion }\end{array}$ & $\begin{array}{l}\text { Civil Serv- } \\
\text { ants Act1 }\end{array}$ & $\begin{array}{c}\text { Civil Serv- } \\
\text { ants Act - } \\
\text { officials }\end{array}$ & $\begin{array}{c}\text { Public Ad- } \\
\text { ministra- } \\
\text { tion Act }\end{array}$ & $\begin{array}{c}\text { General Ad- } \\
\text { ministrative } \\
\text { Procedure Act }\end{array}$ \\
\hline \multicolumn{6}{|c|}{ Special principles of good public administration } \\
\hline Autonomy & $\begin{array}{c}\mathrm{X}- \\
\text { separation } \\
\text { of powers }\end{array}$ & & & $\mathrm{x}$ & $\mathrm{x}$ \\
\hline \begin{tabular}{|l|}
$\begin{array}{l}\text { Political } \\
\text { neutrality }\end{array}$ \\
\end{tabular} & & & $x$ & $x$ & \\
\hline $\begin{array}{l}\text { Professional } \\
\text { conduct }\end{array}$ & & $\mathrm{X}$ & & $x$ & \\
\hline Impartiality & & & $\mathrm{X}$ & $\mathrm{X}$ & Part of legality \\
\hline $\begin{array}{l}\text { Openness, } \\
\text { publicity and } \\
\text { transparency }\end{array}$ & $\mathrm{x}$ & & $x$ & $x$ & \\
\hline $\begin{array}{l}\text { Confidentiality } \\
\text { data protection }\end{array}$ & $x$ & $x$ & & Partly & As a rule \\
\hline \multicolumn{6}{|c|}{ Special principles of good public administration } \\
\hline \begin{tabular}{|l|} 
Use of (official) \\
language
\end{tabular} & $\mathrm{x}$ & & & $x$ & As a rule \\
\hline \begin{tabular}{|l|}
$\begin{array}{l}\text { Client- } \\
\text { orientation }\end{array}$ \\
\end{tabular} & & & & $x$ & $\begin{array}{c}\mathrm{X}- \\
\text { participation } \\
\end{array}$ \\
\hline \begin{tabular}{|l|} 
Protection of \\
public interest
\end{tabular} & $\begin{array}{l}\text { Through } \\
\text { legality }\end{array}$ & & & $x$ & $\mathrm{x}$ \\
\hline $\begin{array}{l}\text { Efficiency and } \\
\text { economy }\end{array}$ & & & & $x$ & $x$ \\
\hline \multicolumn{6}{|c|}{ Professional principles of civil servants } \\
\hline Equal access & $\mathrm{x}$ & $\mathrm{X}$ & $\begin{array}{c}\mathrm{X} \text { - through } \\
\text { open } \\
\text { competition }\end{array}$ & & \\
\hline $\begin{array}{l}\text { Honourable } \\
\text { conduct } \\
\text { (professional } \\
\text { ethics) }\end{array}$ & & $\mathrm{x}$ & & & \\
\hline $\begin{array}{l}\text { (Non) } \\
\text { acceptance of } \\
\text { gifts }\end{array}$ & & $\mathrm{x}$ & & & \\
\hline $\begin{array}{l}\text { Protection of } \\
\text { professional } \\
\text { interests }\end{array}$ & & $x$ & & & \\
\hline $\begin{array}{l}\text { Prohibition of } \\
\text { harassment }\end{array}$ & & $x$ & & & \\
\hline Career & & & $x$ & & \\
\hline Qualification & & $\begin{array}{l}\text { Through } \\
\text { rules }\end{array}$ & & & Through rules \\
\hline
\end{tabular}


Table 2 shows that in Slovenia, several regulations at the highest or more general levels define similar principles, yet a more detailed classification by subject matter reveals that they refer to both democratic principles and professional standards. The legal-political principles can be defined as follows:

- General principles for any social subsystem or uniform principles for all bearers of authority (e.g. equality before the law);

- Principles which are (more) characteristic of public administration than of other bodies and/or the private sector (e.g. boundness by the law and thus limited autonomy or efficiency, impartiality).

As a consequence, officials face specific ethical and legal dilemmas which arise from their relation toward other persons or institutions involved in public management, such as the ambivalence between parties and superiors (cf. Stare 2011, 4, Primožič and Andolšek 2011, 264, 272). Mostly, officials are divided between public interest and other legally protected individual interests (Figure 2), and their duty is to solve this collision in an acute life situation.

Considering the complexity of relations, it is not surprising that several ethical codes have been developed for public administration and officials in Slovenia and throughout the world, intended to give (more) sense to the law that otherwise binds the officials in their work. A classification of such codes reveals that they can be distinguished as follows:

a) They apply to public administration as a system or to officials as a professional group or individuals;

b) They are sampled and adopted in a specific environment;

c) They apply at international, national or municipal levels, or at the level of a single body:25

d) They are either general or partial (applying to parts of the administration or to a certain area of work or to a certain employee profile);

e) They are issued by the principal or developed by the officials themselves;

f) They are abstract and based on values or detailed and containing a definition of due conduct (by appointing the body as a court of honour), etc.

25 Similar results have been obtained in a comparative analysis of other countries: some of them apply general, global codes issued from top to bottom for public administration as a whole or for individual services or officials, e.g. in Italy, UK, Australia, Brazil, Poland, etc. (Stare 2011, 6). Other countries have no code as such and define ethical guidelines in the legal principles of regulations (e.g. Belgium, Finland). 


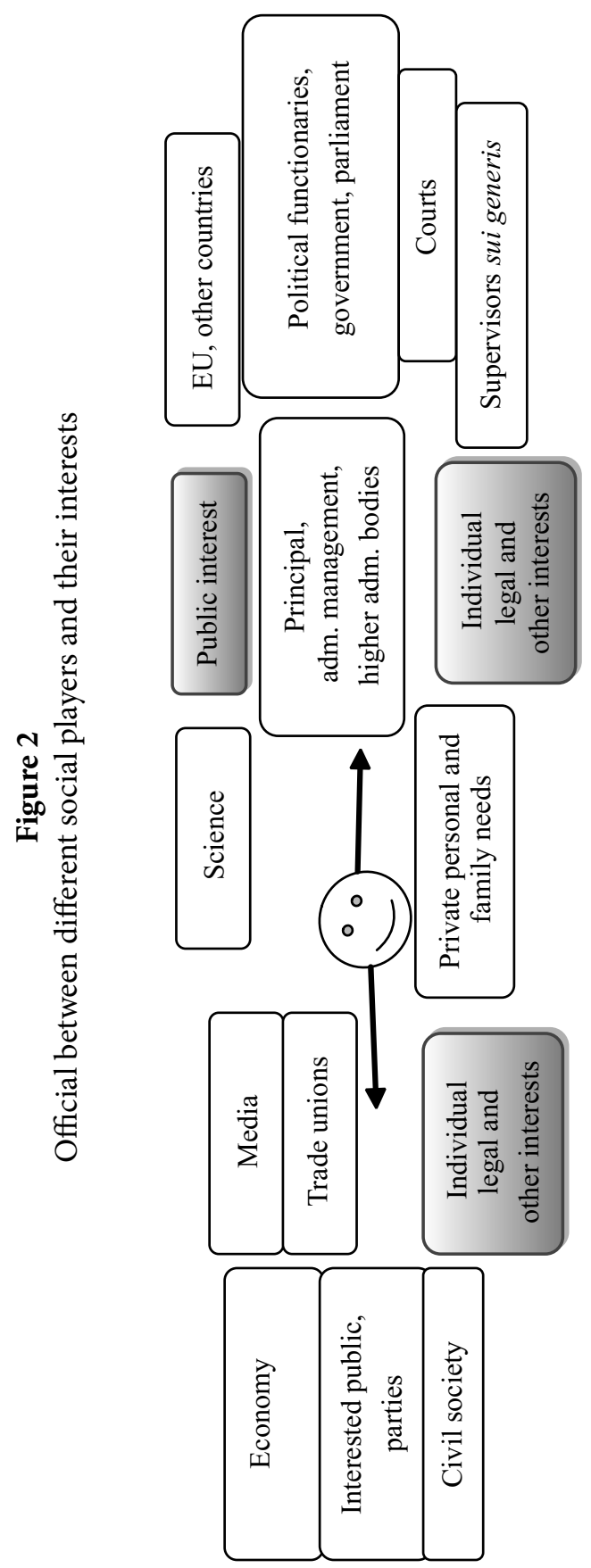


The Slovene administration is mainly governed by professional codes or codes issued by individual bodies. ${ }^{26}$ Such codes were adopted in the Slovene administration as a tool to strengthen appurtenance and administrative (sub)culture (Igličar in Vlaj 2006, 20). Thus, every code presents its own specific features: for example, the code of the Krško Administrative Unit requires quality service and stresses the importance of accepting and responding to criticism and praise (by clients); the code of the Government Protocol Service highlights the flexibility of working hours; the code of state auditors points out that the results of the work must be irreproachable and supported by evidence; the Police code provides for action based on the authority of argument rather than strength; the tax code emphasises protection and confidentiality of data; the military code underlines good physical and mental condition of soldiers, the code of the Ljubljana University highlights commitment to academic excellence. However, the codes applied in the Slovene public administration all share the following characteristics:

- They apply to public administration as a whole, while guidelines and rules at the level of officials are subordinated to their status as employees of public administration or a unit thereof;

- They refer (merely) to a certain profession or position or body;

- They are rather detailed, providing some guidelines but mainly indicating desired and prohibited conduct;

- They are issued by the principal or a hierarchically higher institution - in the best case a more or less representative body of officials in a certain field of work;

- They largely overlap with legal rules, and sanctions are provided in regular legal proceedings. ${ }^{27}$

In order to gather a series of regulations and ethical codes under one single act, Slovenia adopted a joint code of ethics of civil servants in public administration (state bodies and local community administrations) in April 2011, based on Article 174 of the Civil Servants Act. The code was adopted by the Officials' Council, established in 2003 as an apolitical body and comprising mainly representatives of officials (represented directly or through trade unions). Given its composition and powers - particularly the development of professional qualification standards and the code of ethics - the Officials' Council was set up to act as a representative of civil servants, promoting administrative culture, professional conduct and quality

26 Some codes apply to specific professions in the public or private sectors (e.g. medical staff). All the above and similar codes were adopted over the last ten years - prior to that, there had been no codes or rules developed by professional groups themselves.

27 Thus, there is no (direct) case law concerning violations of the codes or ethical norms since disciplinary and similar procedures in public administration as well as labour disputes are conducted based on the Civil Servants Act or the law governing labour relations - hence, violations and sanctions are determined on the basis of legal rules since the codes do not have the legal character of a regulation. 
(Korade-Purg in Brezovšek and Haček 2004, 118). Based on a two-year analysis of existing acts, the Council adopted a code with ten value-based guidelines. More precisely, the code encourages legality and the respect for common good, and regulates the activities of Slovene officials against a European setting (Officials' Council 2011). These three pillars form the basis for guidelines with values and principles that according to the classification above (Table 2) can easily be divided into three groups, also including a fourth group of personal qualities:

1. General political and legal principles: legality, responsibility toward natural and social environments, respect, acting to the benefit of Slovenia;

2. Principles specific to public administration: transparency, professional conduct, effectiveness, efficiency and excellence, cooperation, responsiveness, accessibility, economy, reasonable action and use of data and sources, impartiality and autonomy in relation to private interests;

3. Professional values: competence, conscientiousness, honourable conduct, integrity;

4. Personal and human values: honesty, trustworthiness, sincerity, reliability.

Most elements are listed in the group of principles specific to public administration as it refers to both officials as a professional group and to democracy of authority. Given its characteristics (focused on values, general, adopted based on a bottom-up approach ${ }^{28}$ ), the new code was meant to be more than just plain letters on paper, contrary to the Code of Conduct of Civil Servants that had been adopted in 2001 following the example of Sigma (1998) and the recommendations of the Council of Europe (2000) (although the Government had undertaken to ensure that the employment contract would oblige the civil servant to become familiar with the Code, the latter remained unknown, and violations were never sanctioned). Thanks to the dialogue with the social players, the new code could serve as a basis for and a link between the codes of professional groups and administration units. A contribution thereto can also be made by the provisions of the Civil Servants Act whereby the violations of the code could be considered a minor disciplinary violation ${ }^{29}$

28 The grammar used in the Slovene original implies that the code is written by civil servants themselves (e.g. We, civil servants, act in accordance with the law ... Our actions are transparent and socially responsible ... Our actions are honest ... We are committed to values and mission of our work ...).

29 According to Article 93 of the Civil Servants Act (in the chapter on the rights and obligations of civil servants), civil servants "must perform their work in conformity with regulations, collective labour agreement, the contract of employment, general acts of the body and the code of ethics", while all acts must be issued in conformity with regulations or their provisions shall be void. Article 100 contains explicit indications of the principles of the Act and of the code of the Officials' Council: if in the performance of certain activities the civil servant acts without or contrary to the consent of the principal, this is considered a minor disciplinary violation (e.g. if the activity was contrary to the prohibition of competition or the non-competition clause, or would affect impartiality, or imply abuse of information, or harm the reputation of the body). 
although the code is not a regulation in the classical sense, it has been adopted based on a law. The latter should give the code some extra weight since it has been adopted by civil servants themselves (or their legitimately elected representatives) and is supported by sanctions in case of violations.

\section{Ethical dilemmas about/in the work of Slovene officials}

The work of public administration is indeed multi-layered, but its role in public management or governance, particularly when acting as authority, is crucial. Roughly speaking, officials in public administration act at two separate levels, i.e. (a) regulation and (b) implementation of (administrative) law or public policies. ${ }^{30}$ Public administration as such does not adopt regulations (at the most, rules are issued by the ministry yet exclusively with the minister's signature); the preparation and adoption of legal norms are in fact reserved to politicians even though officials play a key role in the regulatory loop since they prepare the legal expertise for regulations and later implement them. Regulation and implementation, particularly within the scope of authoritative administrative powers, differ in many aspects, e.g. as regards admissibility or amount of political elements compared to strictly professional or explicitly prescribed elements, and the degree of free judgement about general public interest. ${ }^{31}$ Thus, certain ethical dilemmas refer to officials' work in general while some are specific and concern the officials' work in the administrative body and their specific competences. Officials deciding on administrative proceedings in administrative units or tax offices will probably encounter other problems than the co-creators of public policies at ministries or regulatory agencies. In providing public services, teachers and doctors will indeed face different dilemmas than inspectors or police officers carrying out law-enforcement

30 Several authors (e.g. comprehensively Barnes in Rose-Ackerman and Lindseth 2011, 338) argue that given the globalisation trends in public administration, mainly the influence of supranational organisations (EU), the intertwining of public and private (outsourcing), and the expansion of regulatory competences from the parliament and the government to administrative agencies, this separation no longer applies. Thus, also the separation of powers and the resulting role of the administration (e.g. in relation to the Judiciary) are a matter of the past. It is no longer true that the parliament unilaterally adopts regulations and other acts defining public policies, that the government and the administration implement them, and that the Judiciary supervises compliance; all the basic activities of the classic bearers of the three powers are now distributed among all, also the administration. Modern administrative law should therefore uniformly regulate the regulatory and implementation functions of the administration (e.g. in a democratic state, both require the participation of the parties and the openness of authorities). However, the paper maintains said separation of administrative activities as it draws from applicable administrative law in a particularly traditional Slovene setting where conservative practices prevail.

31 Rakar (in Vlaj 2006, 25) adds that owing to greater transparency of the content of interest and its bearer in specific administrative acts, the interest in influence and corruption (at the level of implementation) is greater than in the case of general acts (regulation). Quite the opposite, the established procedures of supervision in the sense of a definite legality test contribute to a lower possibility of influence. 
tasks. For this reason, unethical conduct or corruption can be observed in different activities and parts of public administration. For example, most cases of microcorruption $^{32}$ in the Slovene administration are recorded among officials issuing permits in administrative proceedings while middle and macro corruption are present at local and national levels, respectively; examples of this are found mainly in public procurement (cf. Dobovšek in Brezovšek and Haček 2004, 223, Kovač in Vlaj 2006, 84, Integriteta 2012).

If the above dilemmas or problems are taken as examples and classified according to the above typology of values or principles as universal political and legal principles that are characteristic of a good public administration and professional (Table 2), the whole picture eventually becomes clear. As suggested by Table $3^{33}$, unethical practices are observed in every administrative area and activity although their extent and share compared to lawful and ethical conduct can only be assessed in qualitative or comparable terms, and according to regional studies, Slovenia is an averagely successful European country.

An increasing contribution to the extent of the above defects is made by the economic environment and the economic crisis, to which governments respond - on a short-term basis - merely by reducing the resources (critically thereon for Slovenia in Kovač and Virant 2011, 44, 76). The measures to change the methods of work in the administration should not be supported merely by costs: for example, consensual solving of the collision between public and private interests should not be introduced with the sole aim of disburdening the competent bodies (Harlow and Rawlings 1997, 391). In times of crisis, the effectiveness of both the public sector and (sic!) the economy should increase in order to provide stability and prosperity of the community.

Within public management and administration, the burden of lawful, ethical and effective work is mainly on the management, strategically adapted to social changes. The solution for the above-mentioned and other unethical practices therefore lies in the development of good governance models; this means that based on social identification and promotion of collaborative values, changes should ini-

32 Data from empirical quantitative and quality research, also based on evidence such as unlawful or inexplicable decisions, judgements in similar cases, insufficient documentation, promotion of certain cases only, refusing transfer, etc. Cf. the findings of Dobovšek et al. concerning the National Integrity System for Slovenia and other countries (Integriteta 2012) where in relation to the public sector, authors highlight e.g. frequent political interventions in professional decisions or corruption in human resources, which indeed adds to the impression or objective evidence that the effectiveness of public administration is not optimal.

33 The references or practices are indicated by various sources (in general and separately for the regulatory activity of administration or decision-making in individual administrative matters cf. Boštic et al. 1997, Brezovšek et al. 2004, Vlaj 2006, Kovač and Virant 2011, Igličar 2011, Žagar 2011, Integriteta 2012), which - despite individual subjective assessments - gives the findings a minimum objective weight, particularly when referring to the same conducts or omissions over several decades. 
Table 3

Selected ethical problems by type of activity of officials or public administration

\begin{tabular}{|l|l|l|}
\hline \multicolumn{2}{|c|}{ Common problems of officials/public administration concerning regulation and } \\
implementation
\end{tabular}

\section{Problems arising among officials/public administration in developing laws, regulations and public policies \\ (institutional or strategic instrumental public management)}

\begin{tabular}{|l|l|l|}
\hline Democracy of authority & $\begin{array}{l}\text { Effectiveness of public } \\
\text { administration }\end{array}$ & $\begin{array}{l}\text { Professional conduct of } \\
\text { officials }\end{array}$ \\
\hline Particracy and corporatism & $\begin{array}{l}\text { Normative idealism } \\
\text { (everything can be regulated } \\
\text { (only) by law; law as a } \\
\text { tool for solving non-legal } \\
\text { problems) }\end{array}$ & $\begin{array}{l}\text { Lack of knowledge or } \\
\text { ignorance of legislative } \\
\text { drafting techniques and } \\
\text { better regulation methods }\end{array}$ \\
\hline Too frequent amendments & Casuistic regulation & $\ldots$ \\
\hline $\begin{array}{l}\text { Immediate application of } \\
\text { the "negulations to satisfy }\end{array}$ & $\begin{array}{l}\text { Time pressure due to } \\
\text { urgency of impacts in } \\
\text { practice or among voters }\end{array}$ & \\
\hline $\begin{array}{l}\text { Absence of ex post and } \\
\text { ex ante evaluation, no } \\
\text { accountability ... }\end{array}$ & $\ldots$ & \\
\hline
\end{tabular}


Table 3

(continuation)

\begin{tabular}{|c|c|c|}
\hline Democracy of authority & $\begin{array}{l}\text { Effectiveness of public } \\
\text { administration }\end{array}$ & $\begin{array}{l}\text { Professional conduct of } \\
\text { officials }\end{array}$ \\
\hline Self-will & $\begin{array}{l}\text { Bureaucratism: sticking } \\
\text { to forms and overall } \\
\text { verification of correctness of } \\
\text { decisions (no autonomy, no } \\
\text { assumption of responsibility) }\end{array}$ & $\begin{array}{l}\text { Insisting on wrong past } \\
\text { practices in order not to } \\
\text { jeopardise the equality } \\
\text { between the parties }\end{array}$ \\
\hline $\begin{array}{l}\text { Partiality and thus } \\
\text { unlawfulness due } \\
\text { to jeopardising or } \\
\text { subordinating public interest }\end{array}$ & $\begin{array}{l}\text { No decision or long times for } \\
\text { decision, i.e. delaying the } \\
\text { decision }\end{array}$ & $\begin{array}{l}\text { Subordinating the manner } \\
\text { of work and contents of } \\
\text { decisions to ministries in } \\
\text { order to attain a favourable } \\
\text { administrative statistics, } \\
\text { instead of solving cases } \\
\text { in accordance with the } \\
\text { constitution }\end{array}$ \\
\hline $\begin{array}{l}\text { Disregard of the principles } \\
\text { of fair procedure and the } \\
\text { rights of the parties to } \\
\text { participation due to attempts } \\
\text { to meet the deadlines }\end{array}$ & $\begin{array}{l}\text { Disclosure of confidential } \\
\text { data }\end{array}$ & $\begin{array}{l}\text { No assumption of } \\
\text { responsibility in solving } \\
\text { collisions between opposing } \\
\text { (private) interests }\end{array}$ \\
\hline $\begin{array}{l}\text { Disregard of the basic } \\
\text { procedural safeguards in } \\
\text { service activities }\end{array}$ & $\begin{array}{l}\text { Unlawful assumption or } \\
\text { transfer of competence } \\
\text { among bodies and giving } \\
\text { excessive competence } \\
\text { to officials considering } \\
\text { their status or work post } \\
\text { (inconsistency between } \\
\text { mandate and accountability) }\end{array}$ & $\begin{array}{l}\text { Conflict of interests in local } \\
\text { environment (no exclusion } \\
\text { of the official) }\end{array}$ \\
\hline $\begin{array}{l}\text { Unlawful transfer of } \\
\text { competence to another body }\end{array}$ & $\begin{array}{l}\text { Aggressive attitude by } \\
\text { parties, also through } \\
\text { lawyers, at or beyond the } \\
\text { limits of (ab)use of rights }\end{array}$ & $\begin{array}{l}\text { Insufficient (competent) } \\
\text { staff considering the } \\
\text { competences of e.g. } \\
\text { inspectorates }\end{array}$ \\
\hline $\begin{array}{l}\text { De facto non-devolution of } \\
\text { appeal (the same persons } \\
\text { first drafts the contested } \\
\text { act and later issues the } \\
\text { decision) }\end{array}$ & $\begin{array}{l}\text { Lack of lawfulness, } \\
\text { competence and } \\
\text { accountability (within and } \\
\text { outside administration) }\end{array}$ & $\begin{array}{l}\text { Frequent lack of competence } \\
\text { of officials at higher } \\
\text { (ministerial) level }\end{array}$ \\
\hline $\begin{array}{l}\text { Giving unpublished } \\
\text { instructions to lower bodies } \\
\text { and officials with external } \\
\text { effect for the parties ... }\end{array}$ & $\ldots$ & $\cdots$ \\
\hline
\end{tabular}


tially involve some (although classic) concepts of administrative law, together with the manner of organising and implementing public policies by means of applicable regulations at the operational level. The focus of administrative work should be on results rather than (merely) processes. It would be legally correct as well as moral and ethical if, at abstract and specific levels, officials had the mandate or autonomy to solve (or even prevent) social problems rather than acting bureaucratically and on a routine basis, as long as their "drawer" is neat and tidy. The real touchstone of the officials' ethos is, thus, the degree of responsiveness of public administration and officials as to whether and to what extent they (can) resolve outstanding issues among the participants in public relations. They should not delegate their tasks to others or find excuses in the complexity of regulations (which implies a lack of knowledge or unwillingness to accept responsibility for decisions), but solve the problems of individual parties and of the community as a whole.

\section{Conclusion}

Given the specific importance of public administration in the system of a democratic state, which particularly in a situation of limited resources strives for the effective promotion of the development of the society, the ethical conduct of officials at the individual level and at the level of the system is becoming increasingly important. This applies despite or mainly due to the specific characteristics of the environment, such as demographic or generational changes, globalisation and economic crisis. Officials and public administration must consistently implement public values based on a bottom-up (starting from the officials who have the most direct contacts with the clients, although merely at an operational level) and top-down approach (starting from higher bodies and principals). In addition to more or less plain observance of legality with the emphasis on work processes and hierarchy, the key source of and at the same time a guideline to solve ethical dilemmas of officials is to take account of the intersection of different values. The contradiction between them should become purely artificial, and dilemmas need to be resolved without giving priority to one value over the other, thus satisfying all basic values of public administration: (a) lawfulness with the pursuit of public interest, (b) responsiveness to democratically perceived social needs and procedural participation in defining and implementing public interests, (c) efficiency and effectiveness of organisation and of the implementation of public policies, and (d) individuals' or employees' ethics and integrity. Despite the administration being strictly bound by the law, the law alone cannot be the only way to solve acute situations. In a democratic state, an ethically sustainable decision and conduct will always be indisputable in legal terms. An effort to such should be made by all, both officials and principals and the parties. Public administration is obliged to contribute to legitimate law and has to decide in accordance with the regulations without any exceptions. Therefore, it must assist in bringing regulations - whether and inasmuch they deviate from social reality 
- in line with the tradition of democracy and the endeavours to guarantee an effective protection of the public good and the solution of individuals' social and life issues. Therefore, the main duty and ethical guideline of public administration is and should be a proactive establishment and preservation of community welfare.

\section{References}

Androjna, V. and E. Kerševan. 2006. Upravno procesno pravo [Administrative Procedural Law]. Ljubljana: GV Založba.

Bevir, M. (ed.). 2011. The SAGE Handbook of Governance. Los Angeles: Sage.

Bluhm, W. T. and R. A. Heineman. 2007. Ethics and Public Policy. New Jersey: Pearson.

Boštic, A., M. Košir and V. Rajh. 1997. Etika upravnega dela [Administrative Work Ethics]. Ljubljana: Paco.

Brezovšek, M. and M. Haček (eds). 2004. Upravna kultura. [Administrative Culture] Ljubljana: Faculty of Social Sciences.

European Commission. 2011. "Decision on Code of Good Administrative Behaviour." OJ EU, C 285/03, 5-9. Available at http://eur-lex.europa.eu/LexUriServ/LexUriServ.do?uri=OJ:C:2011:285:FULL:EN:PDF (last accessed 25 February 2012).

European Ombudsman. 2005. The European Code of Good Administrative Behaviour. Luxembourg: Publications Office of the European Union. Available at http://www.ombudsman.europa.eu/code/pdf/sl/code2005_sl.pdf (last accessed 10 March 2012).

Godec, R. (ed.). 1993. Upravni zbornik [Administrative Proceedings]. Ljubljana: Institute of Public Administration.

Harlow, C. and R. Rawlings. 1997. Law and Administration. London: Butterworths.

Hondeghem, A. (ed.). 1998. Ethics and Accountability in a Context of Governance and New Public Management. Amsterdam, Berlin, Oxford, Tokyo, Washington DC, EGPA: IOS Press.

Huberts, L. W. J. C., J. Maesschalek and C. L. Jurkiewicz (eds.). 2008. Ethics and Integrity of Governance (Perspectives Across Frontiers). Cheltenham, Northampton: Edward Elgar.

Igličar, A. 2011. Zakonodajna dejavnost [Legislative Activity]. Ljubljana: GV Založba. 
Integriteta: Association for Ethics in Public Service/Transparency International Slovenia. 2012. National Integrity System. Available at http://www.integriteta. si/projekti/173-nacionalni-sistem-integritete-nis (last accessed 10 March 2012).

Jerovšek, T. and P. Kovač. 2010. Upravni postopek in upravni spor [Administrative Procedure and Administrative Dispute]. Ljubljana: Faculty of Administration.

Koprić, I. 1999. Struktura in komuniciranje u upravnim organizacijama. Zagreb: Pravni fakultet.

Kovač, P. and G. Virant (eds). 2011. Razvoj slovenske javne uprave 1991-2011 [Development of Slovene Public Administration 1991-2011]. Ljubljana: Uradni list RS.

Kustec Lipicer, S. 2009. Vrednotenje javnih politik [Evaluation of Public Policies]. Ljubljana: Faculty of Social Sciences.

Meriac, J. P., D. J. Woehr and C. Banister. 2010. "Generational Differences in Work Ethics: An Examination of Measurement Equivalence across Three Cohorts." Journal of Business and Psychology 25, 315-324.

OECD. 1996. Ethics in the Public Service, Current Issues and Practice. PUMA Occasional Papers 14. Available at http://www.oecd.org/dataoecd/59/24/1898992. pdf (last accessed 15 January 2012).

Officials' Council. 2011. Available at http://www.mju.gov.si/si/delovna_podrocja/ uradniski_svet/ (last accessed 25 February 2012).

Pavčnik, M. 2007. Teorija prava: Prispevek k razumevanju prava [Theory of Law: A Contribution to the Understanding of Law]. Ljubljana: Cankarjeva založba.

Primožič, M. and D. Mesner Andolšek. 2011. "Managerji HRM in njihove etične dileme" [HRM Managers and Their Ethical Dilemmas]. Management 6 (3), 263-281.

Remac, M. and P. Langbroek. 2011. "The Normative Function of Ombudsmen between Citizens, Public Administration and Courts." Paper presented at the EGPA Conference, 7-10 September 2011, in Bucharest. Available at http:// egpa-conference2011.org/documents/PSG10/Remac-Langbroek.pdf (last accessed 25 February 2012).

Rose-Ackerman, S. and P. L. Lindseth (eds). 2011. Comparative Administrative Law. Cheltenham, Northampton: Edward Elgar. 
Stare, J. 2011. "Kodeks etike javnih uslužbencev v državnih organih in upravah lokalnih skupnosti" [Code of Ethics of Civil Servants in State Bodies and Local Community Bodies]. In J. Stare. Odgovornost javnega sektorja. Paper presented at the annual meeting of Slovene administration, 22-24 September 2011 in Portorož. Ljubljana: Faculty of Administration.

Statskontoret. 2005. "Principles of Good Administration in the Member States of the European Union." Available at http://www.statskontoret.se/upload/Publikationer/2005/200504.pdf (last accessed 15 January 2012).

Suwaj, P. J. and H. J. Rieger (eds). 2009. Public Integrity: Theories and Public Instruments. NISPAcee: Bratislava.

Virant, G. 2009. Javna uprava [Public Administration]. Ljubljana: Faculty of Administration.

Vlaj, S. (ed.). 2006. Etično upravljanje občin [Ethical Management of Municipalities]. Ljubljana: Faculty of Administration.

Žagar, K. 2011. "Med etičnim odločanjem in etičnim obnašanjem" [Between Ethical Decisions and Ethical Conduct]. In J. Stare. Odgovornost javnega sektorja. Paper presented at the annual meeting of Slovene administration, 22-24 September 2011 in Portorož. Ljubljana: Faculty of Administration. 